\title{
The Effect Of Role Of Parents On Achievement Of Students Of State Junior High School 27medan
}

\author{
Jannu slumbanga \\ \{Jannuslumbangaol03@gmail.com\} \\ Postgraduate Program, Pelita Kebenaran School of Theology
}

\begin{abstract}
Parents are the figures closest to children and parents are as the first educators in the family, carrying full responsibility for children. In such a case parents have the obligation to provide their children with clothing, food, education and health needs. Parents who do not pay attention to their children or who are indifferent to the learning process of their children, do not want to know the difficulties of their children in learning, do not pay attention to the health of their children, do not guide, direct and motivate their children, apart from not providing comfortable learning places, tables, chairs and sufficient lighting, and others that can inhibit the learning process of children, causing their children to become less capable to follow lessons at school, which results in children underachieving and may even experience failure. On the contrary, parents who always pay attention to their children, especially to children's health and meet all learning requirements, including comfortable study rooms, study desks, appropriate chairs and lighting, and guiding, directing and motivating children will make children more eager to learn, because children realize that not only are they willing to advance, but parents also want them to progress, so that the learning achievements of children will increase.
\end{abstract}

Keywords: Role Of Parents, Achievements, Children.

\section{Introduction}

According to Purwanto (1991: 101) factors that affect children's learning can be divided into two types, namely internal factors and external factors.

There are two internal factors:

1. Physiological factors: These are related to physical condition and senses.

2. Psychological factors: These are related to psychology, i.e., intelligence, motivation, interest, talent,

On the other hand, there are two external factors, namely:

1. Family environment factors. This is where children interact with father, mother, brother and sister who influence their behavior. Parents therefore play an important role in organizing children's learning conditions to support their achievements.

2. School environment factors. This for example are the content of the subject matter, the quality and the way the teacher teaches it, the completeness of school facilities, security, comfort and school friends who support children's learning achievement.

3. Community environmental factors. This is where people in the environment of children with various educational backgrounds, characteristics and ages that are different, then with whom he befriended can influence the interest in learning that has an impact on influencing children's performance. 
The level of children's academic achievement is affected by the role of parents who are very close to children, therefore to improve children's achievement in school education, the active role of parents is very necessary, because parents are the first educators who have an important role in fostering the development of the learning process children, because the education in the school only lasts about 6 hours, namely from 8 a.m. to 13 p.m. every day with various kinds of subjects, therefore parents care to monitor the progress of the child's ability in following lessons, if the child has difficulty then parents must be ready to guide, direct and motivate children, so that children's minds can be opened and have more enthusiasm to learn in order to get better achievements.

\section{Method}

This research uses a descriptive quantitative approach, aiming to provide a systematic description of the current situation in the topic discussed in the research, i.e., the effect of the role of parents on children's achievement in students of State Junior High School 27 Medan.

In the research of students of State Junior High School27 Medan in February 2019 out of 100 students interviewed, data was obtained by taking the average score with the results according to the following table:

Table 1.The Effect of Role of Parents on Achievement of Students of State Junior High School 27 Medan

\begin{tabular}{|c|c|c|c|c|c|c|c|}
\hline & \multirow[t]{2}{*}{ Alternative } & \multicolumn{2}{|l|}{ Often } & \multicolumn{2}{|c|}{ Sometimes } & \multicolumn{2}{|l|}{ Never } \\
\hline & & Students & $\%$ & Students & $\%$ & Students & $\%$ \\
\hline 1. & Giving encouragement & 45 & 45 & 40 & 40 & 15 & 15 \\
\hline 2. & $\begin{array}{l}\text { Guiding children in } \\
\text { studies }\end{array}$ & 57 & 57 & 37 & 37 & 6 & 6 \\
\hline 3. & Being a good role model & 28 & 28 & 52 & 52 & 20 & 20 \\
\hline 4. & $\begin{array}{l}\text { Effective communication } \\
\text { with children }\end{array}$ & 37 & 37 & 49 & 49 & 14 & 14 \\
\hline \multirow[t]{3}{*}{5.} & $\begin{array}{l}\text { Providing educational } \\
\text { needs for children }\end{array}$ & 50 & 50 & 40 & 40 & 10 & 10 \\
\hline & Total & 217 & 217 & 218 & 218 & 65 & 65 \\
\hline & Mean & 43 & 43,4 & 44 & 43,6 & 13 & 13 \\
\hline
\end{tabular}

Based on the table above, it was found that the role of parents on student achievement in State Junior High School27 Medan in the frequency or absence of parental attention to their children as students obtained the following results:

1. Children who often receives attention $=43.4 \%$

2. Children who sometimesreceives attention $=43.6 \%$

3. Childrennever receives attention $=13 \%$ 


\section{Results And Discussion}

Based on the results of the study, the influence of the role of parents on student achievement in State Junior High School27 Medancan be summarized as follows:

1. For the influence of the role of parents on student learning achievement in State Junior High School27 in terms of giving encouragement (children's learning motivation), the percentage of children who responded"often" at $45 \%$, "sometimes" by $40 \%$, and "never" at $15 \%$.

2. For the influence of the role of parents on student learning achievement in State Junior High School27 Medan in terms of aspects of child learning guiding, the percentage of children who responded"often" by $57 \%$, "sometimes" by $37 \%$ and "never" at $6 \%$.

3. For the influence of the role of parents on student learning achievement in terms of good role models, the percentage of children who responded"often" at $28 \%$, "sometimes" at $52 \%$ and "never" at $20 \%$.

4. For the influence of the role of parents on student achievement in Medan Junior High School 27 in terms of aspects of smooth communication with children, the percentage of children who responded"often" by $37 \%$, "sometimes" by $49 \%$ and "never" by $14 \%$.

5. For the influence of the role of parents to complete the child's learning tools, the percentage of children who responded"often"by $50 \%$, "sometimes" at $40 \%$ and "never" at $10 \%$.

By paying attention to the table the influence of the role of parents on student achievement in the State Junior High School27 Medan above, with each alternative multiplied by its weight as follows:

1. Students who answer "often" $=3 \times 217=651$

2. Students who answer "sometimes" $=2 \times 218=436$

3. Students who answer "never" $=1 \times 65=6$

Total $=500=1,152$

All the number of frequencies multiplied by the highest function value, which is 3 (three), then the sum of all frequencies is $500 \times 3=1,500$, -

To find the percentage of research results the author uses the following formula $\mathrm{P}=\mathrm{F} / \mathrm{N} \times 100 \%$, then, $\mathrm{P}=1152 / 1500 \times 100 \%$, the results obtained $\mathrm{P}=76.80 \%$.

In accordance with the standards set, that the results of the percentage of data that are between $76 \%$ - 100\% can be concluded that the influence of the role of parents on student achievement in State Junior High School27 Medan can be categorized in good condition.

Based on the results of the research that the closest and most influential figure to the child is parents, parents therefore must show their desire to monitor the progress of their children's education in daily action/behavior and parents must have good character and should be role models who to the children, so that the children will feel glad to listen and obey the guidance and motivation given by parents do to the child, including the following:

a. Not forcing or determining what the child should like. Every child has their own natural tendency such as intelligence, hobbies, talents and other abilities, parents can direct but do not impose the will, if the child has a special interest in the field that he can do, it is better not to force him to change course.

b. Not ignore the child's progress to achieve success. Children need encouragement, praise and positive input from their parents to give them motivation and encouragement in a better direction, every good thing that is done needs to be appreciated and directed at the right thing if it feels necessary direction. 
c. Not interfering too much in his personal affairs. When a child becomes a teenager and experiences puberty, it's good not to interfere too much with his personal life, just watch him from a distance, and as long as his activities are positive and on track, and not worry too much about what he does.

d. Not criticizing excessively. There are times when children do mischief but that does not mean parents can give scathing criticism to issue high-pitched harsh words that actually make them lose enthusiasm and close themselves and also parents do not need to compare children with other people's children, because every children have their own pace of development.

e. Not speaking harshly to children. Every word that comes out from the mouth of parents to children is education, once parents say rude to children then parents have taught children to behave rudely to others, maybe even to their own parents might say rant.

f. Not lying to the child. If the child knows that his parents are lying, then the child starts not wanting to obey his parents, because he doubts the truth.

g. Being a good listener. Some parents are bad listeners to their children's explanations, if parents don't listen to the child's reasons, the child will be a bad listener to their parents.

h. Not always fulfilling he child's request or be too soft on the child. Affection does not have to be shown by obeying his wishes, if parents really love children, then parents must teach him about the good and bad values as well as the right and wrong that may or may not, excessive love that always follows the child's request will make the child selfish and all I want to be called spoiled children.

i. Not giving bad nicknames to children. Giving bad nicknames to children can lead to inferiority / insecurity, hatred and possibly resistance, you should replace the nickname with a good name such as a good child, great child, wise child, if you can't find a suitable name, simply by calling his favorite name

j. Not teaching children to repay bad treatment from their friends. Some parents can not wait to see their children hurt by others, so he provokes his children to reciprocate, this directly teaches children revenge, do not be surprised if our children often reply or reverse what we convey to her.

\section{Conclusion}

From the explanation outlined above, it can be concluded that the active role of parents in paying attention to health, direct, guide, motivating and providing all school needs of children have a significant effect on improving children's learning achievement. In day-to-day activities at school, teachers often face the situation where even though students are given lessons with the same learning material in the same time, place, and learning methods, the results obtained are different, this is due to obstacles in student learning. It is for this reason that serious attention from parents is needed in order for children to bale to overcome the obstacles in learning process. 